\title{
The Pitfalls of International Integration: A Comment on the Bush Proposal and its Aftermath
}

REUVEN S. AVI-YONAH

aviyonah@umich.edu

The University of Michigan Law School, 625 S. State Street, Ann Arbor, MI 48109

\begin{abstract}
In January 2003, the Bush Administration proposed a new system for taxing corporate dividends, under which domestic shareholders in U.S. corporations would not be taxed on dividends they received, provided the corporation distributed these dividends out of after-tax earnings (the "Bush Proposal"). The Bush Proposal was introduced in Congress on February 27, 2003. Ultimately, however, Congress balked at enacting full-fledged dividend exemption. Instead, in the Jobs and Growth Tax Relief Reconciliation Act of 2003 ("JGTRRA") as enacted on May 28, 2003, a lower rate of $15 \%$ was adopted for dividends paid by domestic and certain foreign corporations, ${ }^{1}$ and the capital gains rate was likewise reduced to $15 \%$. Significantly and in stark contrast to the original Bush proposal, under JGTRRA the lower rate for dividends and capital gains does not depend on any tax being paid at the corporate level.

This comment will focus primarily on the international aspects of both the Bush Proposal and JGTRRA. I will not lay out the proposal or the law in any detail. Instead, I will ask whether either the Bush Proposal or JGTRRA make sense from an economic efficiency perspective when the international implications are taken into account. I will leave to others the question of whether either the Bush Proposal or JGTRRA are sensible ways to stimulate the economy (for discussion of the effect of the 2001 tax cuts see Shapiro and Slemrod, 2001, 2002). I will also omit any discussion of the distributive effects of either the Bush Proposal or JGTRRA, which have been extensively discussed elsewhere (e.g., Tax Policy Center, 2003; Burman, Gale and Orszag, 2003).
\end{abstract}

Keywords: international taxation, integration, dividends

JEL Code: H25

\section{The Bush Proposal and JGTRRA as Methods of Achieving Integration}

Both the Bush Proposal and JGTRRA can be seen as ways of achieving full or partial integration of the corporate and shareholder tax through a reduced tax rate on dividends. Achieving integration has been a long held aim of many tax academics, and was proposed by the first Bush Administration and by the American Law Institute (Graetz and Warren, 1998; Treasury, 1992; McLure, 1979; but see Kwall, 1990). In this section, I will evaluate the traditional arguments for integration, and then assess how the Bush Proposal and JGTRRA fulfill the stated goals of integration.

Historically, there have been three reasons advanced for countries to adopt corporate/ shareholder integration and thus overcome biases in the classical system (Graetz and Warren, 1998): 
1. Under the classical system, there is a bias to conduct business in non-corporate forms, to avoid double taxation of corporate income (although this is mitigated if the individual rate exceeds the corporate rate, since in corporate form the individual tax can be deferred).

2. Under the classical system, there is a bias to avoid dividend distributions and instead retain earnings, thus avoiding the double tax (this bias is exacerbated when the individual rate exceeds the corporate rate);

3. Under the classical system, there is a bias in favor of capitalizing corporations with debt (producing deductible interest) rather than equity (producing non-deductible dividends).

None of these arguments are completely convincing, which may be a reason why the US has maintained the classical system from 1936 to 2003, and indeed strengthened it in 1986 with the repeal of the "General Utilities" doctrine, which had enabled corporations to avoid corporate tax on a distribution of appreciated assets (for other reasons see Bank, 2002; Arlen and Weiss, 1995). First, the alleged bias against the corporate form is mitigated to the extent the top individual rate exceeds the corporate rate, as it generally did until JGTRRA, and by the absence of strong provisions to prevent retentions in the domestic context. ${ }^{2}$

In addition, under current rules, the classical system applies primarily to large, publicly traded corporations, while small, closely held businesses are able to avoid the double tax even if they are in corporate form for non-tax purposes (by choosing to be taxed as $S$ corporations or by incorporating as Limited Liability Companies, which are treated as pass-through entities for tax purposes). It is doubtful if there is sufficient substitutability between the two forms of business for the double tax to create much deadweight loss from the bias toward non-corporate form. Most estimates of the deadweight loss from this bias are quite low. For example, Goolsbee (2002) found that an increase in the corporate tax rate by $10 \%$ reduces the corporate share of firms by $5-10 \%$ and the corporate share of sales and employment by $2-6 \%$. Goolsbee concluded that " $[\mathrm{t}]$ he impact of tax rates is an order of magnitude larger than previous estimates ... and suggests a larger DWL from corporate taxation, but is still relatively modest." As Goolsbee says, previous empirical studies found much lower DWLs (contrary to the theoretical predictions of high DWLs in the model employed by Gravelle and Kotlikoff, 1989). The double tax is a price large businesses have to pay for access to the public equity markets and the liquidity that accompanies such access.

Finally, to the extent that the corporate tax can be shifted to consumers or to labor, the bias disappears, and the Treasury's 1992 integration study and many others have suggested that considerable shifting can take place (Graetz and Warren, 1998; see also Mulligan, 2002; Fullerton and Metcalf, 2002; Judd, 1985; Homma, 1981; Grieson, 1975; Feldstein, 1974, all refining the classic work of Harberger, 1962, who predicted a partial shift primarily to other capital, with all capital ultimately bearing the burden of the tax). The bias reappears if non-corporate businesses can likewise shift the individual tax burden, but it seems plausible that the shifting potential of large multinationals is larger than that of small, closely held businesses (Fullerton and Metcalf, 2002; Harberger, 1995; Mutti and Grubert, 1985).

Second, the bias in favor of retentions is reduced when (as both before and after JGTRRA) the individual rate on dividends is not significantly higher than the corporate rate. In addition, this bias was mitigated before JGTRRA by the ability of corporations to redeem shares from shareholders at the favorable capital gains rate through share repurchases, and by the fact that numerous shareholders are tax exempt or corporate (and thus do not pay a full tax on 
dividends). Even when the tax rate on dividends is the same as that on capital gains (as under JGTRRA), capital gain transactions may still be preferred for the ability to offset basis. That is why many US corporations have adopted structured redemption programs addressed to their taxable individual shareholders. Other corporations retain all their earnings, but it is not clear that this is primarily tax motivated (corporations used to pay dividends under the same rules in the past). Admittedly, more corporations were paying dividends in 2003 than in previous years, but this trend began before JGTRRA (Norris, 2003), and again it is not clear that this is primarily tax motivated. Finally, there is an unresolved debate among economists whether the dividend tax is capitalized into the price of the shares. If it is, then the retention bias applies only to new equity, but new equity is unlikely to pay dividends for non-tax reasons (Fuest and Huber, 2000; Boadway and Bruce, 1992; Bradford, 1981). ${ }^{3}$

Third, the bias in favor of debt and against equity is a general problem of the income tax, which should not be addressed only in the corporate tax area (Warren, 1993; Bradford, 1981; Stiglitz, 1973). Moreover, even to address it just for corporations it is necessary to make dividends not exempt, but rather deductible, a form of integration that is never adopted (in part because it would automatically extend integration to foreign and taxexempt shareholders; see Grubert and Mutti, 1994). If integration takes the normal forms of imputation or dividend exemption, there is still a difference in treatment between interest and dividends that can be manipulated. For example, if interest is taxed at the corporate level but dividends are not, clientele effects will still exist (tax exempts will hold bonds and taxable shareholders stock, and taxable investors will purchase stocks and then use derivatives to construct a portfolio that is economically equivalent to an investment in bonds (Warren, 1993)). Neither of these problems arises if both interest and dividends are deductible or (as under the Treasury's CBIT (Comprehensive Business Income Tax) model, Treasury, 1992) both non-deductible, but neither of these seems to be a practical option politically.

Neither the Bush Proposal nor JGTRRA adequately addresses all of these biases. Under the Bush Proposal, the first bias (against the corporate form) is addressed by taxing corporate profits at $35 \%$ at the corporate level and non-corporate profits at $35 \%$ at the individual level, but if the corporate tax can be shifted more easily than the individual tax (e.g., because multinational corporations can credibly threaten to shift jobs overseas), a bias in favor of the corporate form arises. JGTRRA does nothing to address this bias because the lower rate for dividends does not depend on corporate tax being paid, and therefore if the corporate tax can be sheltered a bias is created in favor of corporate investment (taxed at 15\%) vs. non-corporate investment (taxed at 35\%).

Under the Bush Proposal, the second bias (against distributions) is reduced because dividends are exempt, but capital gains transactions are still taxed differently (at $20 \%$ with an offset for basis that is increased by retained earnings). Under JGTRRA, this bias is retained to the extent dividends are taxed, and capital gains transactions are still preferred for the ability to offset basis. Moreover, to the extent the dividend tax is capitalized into the price of shares, no gain in efficiency can be expected from reducing the dividend tax on old equity, in which case the only outcome is a windfall for existing shareholders.

Finally, neither the Bush Proposal nor JGTRRA adequately address the bias in favor of debt, because under both, equity is still treated differently than debt and this distinction can be manipulated as explained above. 
In sum, it is unclear whether there are significant domestic efficiency gains associated with either the Bush Proposal or JGTRRA. The presumed gains (Treasury, 2003) depend on assumptions regarding the incidence of both the corporate tax and the dividend tax that most economists regard as unproven (Burman, Gale and Orszag, 2003).

\section{The International Aspects of the Bush Proposal and JGTRRA}

Even if one accepts the validity of all the biases generated by the classical system set out above, all of them need to be offset by the countervailing biases created by integration in the international context. From a theoretical perspective, two situations need to be considered: when the source country is integrationist and the residence country classical, and when the source country is classical and the residence country integrationist. In the following, I will first lay out the theoretical problem, and then apply it to the Bush Proposal and to JGTRRA.

\subsection{Classical Residence Country and Integrationist Source Country}

If a portfolio investor residing in a classical country invests in shares of a company of an integrationist country, the resulting bias depends on the form of integration. If the source country grants integration in the form of dividend exemption, the classical country investor would not benefit since the classical country would tax him on the dividend without allowing a foreign tax credit for underlying corporate taxes. A domestic investor in the source country would be subject only to the corporate tax, while the classical country investor would be subject to the corporate tax, any foreign withholding tax on dividends, and the residual classical country tax.

If the source country grants integration by way of imputation credits, the key issue is whether such credits are extended to foreign investors (by treaty or otherwise). If (as is typical) the credits are not extended to foreigners, a domestic investor in the source country would only be subject to tax at his or her individual rate, while the classical country investor would be subject to tax at the corporate level, any withholding tax on dividends, and the residual classical country tax. Whether the combination of these taxes exceeds the source country tax on domestic investors depends on how high the source country rates are (it is conceivable, for example, that a combined tax on the classical country investor of $60 \%$ would be matched by the single level source country tax on a domestic investor).

If imputation credits are extended to classical country investors, a different bias arises. In that case, both domestic source country and classical country investors in a foreign corporation would be taxed the same by the source country, but the cost of imputation credits to classical country investors would be borne by the source country, while any tax on the dividend would be collected by the classical country. From a classical country perspective, moreover, there would be a bias in favor of investing in source country corporations and against investing in classical country corporations, since only dividends from the former would carry the imputation credits. Such a bias would not be eliminated by the classical country taxing the dividends in full, since the investor would still receive an imputation credit check from the source country not available for her classical country investment. 


\subsection{Classical Source Country and Integrationist Residence Country}

If the integrationist residence country grants integration by way of dividend exemption, presumably the exemption would apply to dividends from the classical country as well as from domestic corporations (this is true for many dividend exemption countries but not for others, and is generally true under JGTRRA but not under the Bush Proposal). In that case, a bias is created in favor of foreign investors in classical source country companies, since foreign investors would be exempt from tax on the dividend (unless a classical country withholding tax applies or is designed to offset this problem, but such taxes are generally reduced by treaty or avoided by other devices). By contrast, a classical country domestic investor would be taxable on the dividends in full.

If the foreign country grants integration by way of imputation credits, there will be no credits available for a foreign investor who invests directly in a classical country company. In that case, there will be a bias in favor of the foreigner investing in her own country's domestic corporations. This bias may be partially eliminated if credit is given for classical country taxes to a domestic portfolio investor in a domestic company with classical country source income. But, similar to the case of a dividend exemption, that would create a bias in favor of foreign investors in such companies over classical country investors in a domestic classical country corporation.

Thus, from a theoretical perspective, as long as there are both classical and integrationist countries in the world, integration creates biases that do not arise in a world with only classical countries (Zee, 2002; Avi-Yonah, 1996; Harris, 1996; Ault, 1992). Theoretically, the biases could also be eliminated in a world in which all countries practiced integration and extended its benefits to foreign investors and investments, but this seems a very unrealistic scenario, which is certainly not fulfilled under present conditions.

\subsection{The Bush Proposal and JGTRRA}

Under the Bush Proposal, dividend exemption only applied to dividends from domestic corporations, which were exempt if the corporation's income was fully taxed. This was true even if the dividend derived from US corporations with foreign source income (through a branch or subsidiary), since both direct foreign taxes and withholding taxes could be counted as equivalent to US taxes. Dividends from foreign corporations, on the other hand, were fully taxed, with a credit available only for foreign withholding taxes and for US taxes on effectively connected income. Significantly, US portfolio investors investing in foreign corporations with US source income would not get a credit even for US withholding taxes or branch profit taxes. The Bush Proposal thus created a very significant bias against investing in foreign corporations. In the context of an open economy, this bias could well lead to greater welfare losses to US portfolio investors than their gains from domestic integration.

JGTRRA does better in this regard since it applies the lower 15\% rate to dividends from foreign corporations resident in treaty countries approved by the IRS, as well as from domestic corporations. This still creates a bias against investing in other foreign countries, which is strange since JGTRRA makes no effort to ensure that a corporate tax is levied 
on domestic US corporations (presumably, the restriction was applied to, e.g., Barbados because of the lack of corporate tax there). ${ }^{4}$ Nevertheless, JGTRRA creates another bias in terms of the sourcing of equity capital to US corporations, since they would have an incentive to raise such capital domestically ( $15 \%$ tax on dividends) rather than from foreign investors in classical countries or integrationist countries that do not extend dividend exemption to foreign investments (US withholding tax at $15 \%$ plus residual residence country tax). In addition, corporations in classical countries may be biased in favor of raising capital from US investors rather than from domestic investors.

Thus, both the Bush Proposal and JGTRRA illustrate the theoretical point made above: In a world with both integrationist and classical countries, adopting integration leads to biases that could well result in larger efficiency costs than the putative domestic efficiency gains, especially if (as under the Bush Proposal and under the practice in many integrationist countries (Vann, 2003; Ault, 1997; Harris, 1996)) integration is not extended to foreign investments.

\section{Conclusion}

From a theoretical perspective, there seems to be no reason to assume that the biases created by integration from an international perspective are less important than the biases created by the classical system from a domestic perspective. ${ }^{5}$ Further empirical work is needed on this issue, expanding the initial work by Grubert and Mutti (1994). This is particularly important since the international biases may be gaining in importance as crossborder portfolio investment grows, while (as discussed above) there are reasons to doubt the importance of the latter. ${ }^{6}$ This is the reason why many countries (e.g., Germany and the U.K.) have recently been restricting integration (Vann, 2003). ${ }^{7}$ If the whole world reverted to the classical system, the international biases would be eliminated.

Nevertheless, in the foreseeable future, some countries will continue to grant integration, while others are likely to maintain a classical system. In that situation, it is necessary to make a choice between the international biases described above, which is similar to the choice between capital import neutrality (treating all investors in the source country alike) and capital export neutrality (treating all investment opportunities to a resident investor alike). Since most of the empirical evidence continues to suggest that the elasticity of the demand for capital is greater than the elasticity of the supply of capital, most economists would support a continued preference for capital export neutrality (neutrality in the allocation of investments) over capital import neutrality (neutrality in the allocation of savings) (but see Desai and Hines (2003) for a different view, which applies primarily to direct investment).

If one prefers capital export neutrality, this suggests that integrationist source countries should not extend integration benefits to foreign investors (since that would violate Capital Export Neutrality (CEN) while maintaining Capital Import Neutrality (CIN)). This is consistent with current practice. When the integrationist country is the residence country, integration benefits should be extended to investments in classical source countries. This can be done by granting integration credits for taxes paid to the source country, either through a domestic corporation (which is common) or even through a foreign corporation 
(less common but possible-it is equivalent to granting the indirect foreign tax credit to portfolio US investors, which would raise many difficult administrative issues). A simpler solution, however, is to exempt dividends from both domestic and foreign corporations, as is partially achieved under JGTRRA (but emphatically not under the Bush Proposal). This would still leave a bias in the form of a dividend withholding tax imposed by the source country (plus a branch profits tax if the investment is through a foreign corporation), but in the case of the US, portfolio investors can usually avoid the dividend withholding tax. ${ }^{8}$

Thus, the JGTRRA method of integration (partially exempting dividends from both domestic and foreign corporations) is superior from an international perspective to the Bush Proposal. The JGTRRA result preserves CEN as far as the US is concerned, but there is still a bias in favor of investing in domestic corporations to the extent foreign source countries levy a withholding tax on dividends, a bias that could be eliminated by the source country. In addition, foreign investors in US corporations are still disadvantaged compared to US investors, either because of US withholding taxes on dividends (which the US can and should abolish, see Avi-Yonah, 1996) or because their country of residence taxes dividends (which the US can do nothing about).

However, the best solution from a US perspective to the above biases is to revert to the classical system, as the case against it is shaky (at best). Under current law, this will occur automatically in 2013. In that case, we should consider abolishing the withholding tax on dividends (and the branch profits tax) so as to do our part to reduce the bias against investors from integrationist countries.

\section{Acknowledgments}

I would like to thank Steve Bank, Michael Barr, David Bradford, Bill Gale, Michael Graetz, David Hasen and Emil Sunley for helpful comments on earlier versions of this paper, and David Lenter for excellent research assistance.

\section{Notes}

1. The lower rate applies to dividends from "qualified foreign corporations", i.e., corporations in countries with which we have a tax treaty that the Treasury deems satisfactory.

2. The accumulated earnings tax, IRC 531-537, and the personal holding company tax, IRC 541-547, are both weak, the former because the IRS has to prove that earnings were improperly accumulated, and the latter because it only applies to a narrow class of corporations earning mostly passive income.

3. This "new" view of dividend taxation also implies that the distortion against the corporate form should not be large, which is consistent with Goolsbee (2002) and related work cited above.

4. It may be easier to determine which countries have a zero tax rate than which corporations do not pay much corporate tax, but other integrationist countries do both (Vann, 2003).

5. The former biases may be more important in the short run from a global efficiency perspective, while the latter may be more important from a domestic efficiency perspective. In the long run, however, the two tend to converge for open economies.

6. Admittedly, conducting empirical work that yields clear results is very difficult, and depends crucially on the details of the actual integration proposal. Compare Grubert and Mutti (1994) with Treasury (1992, 2003). While the Bush Proposal remains theoretical, the effects of JGTRRA need to be studied in practice. 
7. In the EU case, part of the motivation was an unwillingness to extend imputation credits to residents of other EU countries as required by the European Court of Justice, but this is a global trend (Vann, 2003), not just a European one.

8. For example, by entering into a total return equity swap with a U.S. investment bank, since dividend equivalent payments under such swaps are not subject to withholding tax (Avi-Yonah and Swartz, 1997).

\section{References}

Arlen, J. and D. M. Weiss. (1995). “A Political Theory of Corporate Taxation,” Yale Law Journal 105, 325-390. Ault, H. J. (1992). "Corporate Integration, Tax Treaties and the Division of the International Tax Base: Principles and Practices," Tax Law Review 47, 565-608.

Ault, H. J. (1997). Comparative Income Taxation: A Structural Analysis. Amsterdam: Kluwer Academic Publishers.

Avi-Yonah, R. S. (1996). “The Structure of International Taxation,” Texas Law Review 74, 1301-1359.

Avi-Yonah, R. S. and L. Z. Swartz. (1997). “U.S. International Treatment of Financial Derivatives,” Tax Notes 74, 1703-1737.

Bank, S. A. (2002). “Corporate Managers, Agency Costs and the Rise of Double Taxation,” William \& Mary Law Review 44, 167-216.

Boadway, R. and N. Bruce. (1992). "Problems with Integrating Corporate and Personal Income Taxes in an Open Economy," Journal of Public Economics 48, 39-66.

Bradford, D. F. (1981). "The Incidence and Allocation Effects of a Tax on Corporate Distributions," Journal of Public Economics 15, 1-22.

Burman, L., W. Gale and P. Orszag. (2003). "Thinking Through the Tax Options," Tax Notes 99, 1081-1105.

Desai, M. A. and J. R. Hines Jr. (2003). “Evaluating International Tax Reform,” National Tax Journal 56, 487502.

Feldstein, M. (1974). "Incidence of a Capital Income Tax in a Growing Economy with Variable Savings Rates," The Review of Economic Studies 41, 505-513.

Fuest, C. and B. Huber. (2000). "The Optimal Taxation of Dividends in a Small Open Economy," CESifo Working Paper No. 348

Fullerton, D. and G. E. Metcalf. (2002). “Tax Incidence.” In Alan J. Auerbach and Martin Feldstein (eds.), Handbook of Public Economics. Elsevier Science BV.

Goolsbee, A. (2002). "The Impact and Inefficiency of the Corporate Income Tax: Evidence from State Organizational Form Data,” NBER Working Paper 9141.

Graetz, M. J. and A. C. Warren Jr. (1998). Integration of the US Corporate and Individual Income Taxes: The Treasury Department and American Law Institute Reports. Tax Analysts.

Gravelle, J. G. and L. Kotlikoff. (1989). "The Incidence and Efficiency Costs of Corporate Taxation When Corporate and Noncorporate Firms Produce the Same Good," Journal of Political Economy 97, 749-780.

Grieson, R. E. (1975). “The Incidence of Profits Taxes in a Neo-Classical Growth Model,” Journal of Public Economics 4, 75-85

Grubert, H. and J. Mutti. (1994). "International Aspects of Corporate Tax Integration: The Contrasting Role of Debt and Equity Flows," National Tax Journal 47, 111-133.

Harberger, A. (1962). "The Incidence of the Corporation Income Tax," Journal of Political Economy 70, $215-240$.

Harberger, A. (1995). "The ABCs of Corporate Tax Incidence: Insights into the Open Economy Case." In Tax Policy and Economic Growth, Washington, D.C.: American Council for Capital Formation.

Harris, P. A. (1996). Corporate/Shareholder Income Taxation. Amsterdam: IBFD.

Homma, M. (1981). "A Dynamic Analysis of the Differential Incidence of Capital and Labour Taxes in a Two-Class Economy,” Journal of Public Economics 15, 363-378.

Judd, K. L. (1985). "Redistributive Taxation in a Simple Perfect Foresight Model," Journal of Public Economics $28,59-83$.

Kwall, J. L. (1990). “The Uncertain Case Against the Double Taxation of Corporate Income,” North Carolina Law Review 68, 613-657.

McLure, C. E., Jr. (1979). Must Corporate Income Be Taxed Twice. Brookings Institution. 
Mulligan, C. B. (2002). “Capital Tax Incidence: First Impressions from the Time Series," National Bureau of Economic Research, Working Paper 9374.

Mutti, J. and H. Grubert. (1985). "The Taxation of Capital Income in an Open Economy: The Importance of Resident-Nonresident Tax Treatment," Journal of Public Economics 27, 291-309.

Norris, F. (2003). "Reversing Trend, Number of Dividend Increases Grows," New York Times, C3.

Shapiro, M. D. and J. Slemrod. (2001). “Consumer Response to Tax Rebates,” NBER Working Paper 8672.

Shapiro, M. D. and J. Slemrod. (2002). "Did the 2001 Tax Rebate Stimulate Spending? Evidence from Taxpayer Surveys,” NBER Working Paper 9308.

Stiglitz, J. E. (1973). “Taxation, Corporate Financial Policy, and the Cost of Capital,” Journal of Public Economics 2, 1-34.

Tax Policy Center. (2003). “Analysis of Distributional Impact of JGTRRA.” Available at http://taxpolicycenter.org/ TaxModel/tmdb/tmtemplate.cfm\#agree

U.S. Department of the Treasury. (1992). Integration of the Individual and Corporate Tax Systems: Taxing Business Income Once, U.S. GPO.

U.S. Department of the Treasury. (2003). “A Dynamic Analysis of the President's Jobs and Growth Plan,” Mimeograph.

Vann, R. J. (2003). "General Report: Trends in Company/Shareholder Taxation: Single or Double Taxation?" Cahiers de droit fiscal international LXXXVIIIa, 21-70.

Warren, A. C., Jr. (1993). "Financial Contract Innovation and Income Tax Policy," Harvard Law Review 107, $460-492$.

Zee, H. (2002). “Taxing Capital in a Globalized World,” Tax Notes International 27, 1185-1204. 